become more and more a public health problem in the future. Control of disease and the resulting increase of the population are leading to increasing numbers of old people and children, who are particularly liable to domestic accidents. Mechanization in the home also tends to increase their number and variety.

No. 27 of the same series is entitled T'rends in the Study of Morbidity and Mortality, and it contains articles on this subject by fourteen contributors (World Health Organization. Public Health Papers, No. 27: Trends in the Study of Morbidity and Mortality. Dario Curiel and thirteen other authors. Pp. 196. Geneva: World Health Organization; London: H.M.S.O., 1965. 8 Sw. francs; $13 s .4 d . ; 2.27$ dollars). In general, the articles survey the methods now in use for obtaining statistics on morbidity and mortality in the United Kingdom, Europe, Romania, Japan and India, and the problems of making the data obtained internationally comparable. There is need for further research into methods of reporting and for the establishment of some degree of uniformity.

\title{
RESEARCH FACILITIES AVAILABLE TO INDUSTRY AND THEIR INTER-RELATION
}

\begin{abstract}
CLOSER collaboration between industrial, govern1 mental, academic and independent research establishments was the principal theme and objective of the symposium arranged jointly on September 14, 1965, by the Scottish Office of the Ministry of Technology and the Arthur D. Little Research Institute, at the Royal Society of Edinburgh. The seven speakers at the symposium were ollowed by Sir Harry Melville, who deseribed the varied work of the newly formed Science Research Council, of which he is chairman, this lecture being the first of the Arthur D. Little 1965-66 series of Acorn Lectures on various scientific topics.
\end{abstract}

Mr. P. M. Thomas (managing director, William Beardmore and Co., Ltd.), in the chair for the morning session, directed attention to the necessity for industry to make proper use of research facilities and so be aware of the present status of any topic relevant to the particular industry and the appropriate place to which to direct problems.

Prof. Manfred Gordon (Department of Physical Chemistry, University of Strathclyde) said that his University, formerly the Royal College of Science and Technology, always had a technical bias and strong links with industry. For example, the idea of industrial liaison officers, whose purpose is to establish co-operation between an academic establishment and industry, originated in 1956 at the then Royal College of Science and Technology. The University and the National Engineering Laboratory have special relationships and that some of the National Engineering Laboratory staff are registered as Ph.D. students. Many of the University staff act as consultants, but Prof. Gordon expressed the desirability of younger membors spending a few weeks of the summer vacation in industry. Strathclyde now uses closed-circuit television for teaching, which could be a valuable technique to assist firms with their training problems. The computer service at the University was also mentioned.

Dr. Magnus Pyko (manager, Glenochil Research Station, Distillers Co., Ltd.) recalled that a few years ago some firms believed in leaving the research staff alone, in the hope that profitable ideas and processes would emerge. This procedure was found very expensive and not very profitable. To-day, practical problems are chosen for the research staff. However, Dr. Pyke stressed that applied research should be tackled at an intellectual depth in order for the results to be financially worth-while and stimulating to the staff. Non-secret technical know-how should be more widely disseminated between firms by porsonal contacts and a new journal.

The problem of assimilating the scientific literature could, he suggested, be solved by using computers to store information which would be released by 'telephoning'. Dr. Pyke, like other speakers, deplored the gap between industry and academic establishmonts in Britain, a situation which does not occur to the same extent on the Continent or in the United States, and called for more industry-orientated projects for research students in order to counteract an 'ivory tower' attitude.

Mr. F. D. Penny (deputy director, National Engineering Laboratory) gave a short historical survey of Government laboratories. Initially, during the seventeenth and eighteenth centuries, these were for defence purposes; later, civil laboratories were established, the Geological Survey being founded in 1835 and the Inland Revenue Laboratory in 1842. Others, of which the National Physical Laboratory was the first in 1900, were intended to determine fundamental and applied, standards. In 1915 the important White Paper setting up the Department of Scientific and Industrial Research, which represented a conscious effort by the Government, appeared to take responsibility for improving industrial progress. Research programmes were not evolved in isolation but were controlled by committees of leading academics and industrialists.

The National Engineering Laboratory was opened in 1947, and, as with other Government laboratories, the work can be classified as follows: (1) particular problems -testing and longer-term research (the latter represents 10 per cent of the total work at the National Engineering Laboratory); (2) safety, for example, tests on gas cylinders; (3) problems applicable to a class of industry but not sponsored by any firm, for example, investigations of metal fatigue; (4) special facilities--testing of pumps and turbines; (5) research in a field of industrial im. portance in which the Government believes there should be a greater rate of innovation; (6) standards of goods for export; (7) advisory services.

The National Engineering Laboratory issues reports $(8,000$ total so far) and papers in scientific journals, welcomes visitors and holds open days. The total staff is 800 , and they spend about half their time on research and half on application.

Dr. H. P. Stout (director of research, British Jute Trade Research Association) pointed out how a research association benefits especially the smaller firms of an industry, since such firms usually cannot afford adequate scientific staff and, where facilities are available, may have difficulty in the recruitment of staff because there is no suitable environment for them. The research association can provide a scientific atmosphere, but there is still the problem of getting en rapport with the firms. Commenting on the statement sometimes heard that arts graduates were more use as management material than science graduates, he thought this was usually the result of the scientist boing given a specialist function and not acquiring the broad training and experience which was given to the arts man. Dr. Stout noted that innovation costs money and manufacturers are unwilling to develop ideas where the market is small, even after the research association has done the "spade work'. He instanced new weaving machinery developed 
for the woollen and cotton industry which had not been adapted for the jute industry because of its comparatively small size.

Oponing the afternoon session, the chairman, Dr. E. A. C. Chamborlain (divisional chiof scientist, National Coal Board), questioned whether Britain was really research-oriontod and said that Britain tonds to ignoro the real achievements which havo boen made. Personial contact is essential to break down the barriers of ignorunee, laziness and snobbory betwoon seiontists, technologists and industrialists, and he therofore welcomed this symposium.

Dr. F. N. Woodward (diroctor, Arthur D), Little Research Instituto) recalled the Jubilee Memorial Lecture given to the Society of Chemictl Industry by Prof. J. W. Mitchell, in which ho depicted the four sources of scientific information, that is, industry, academic institutions, Govornment laboratorios and sponsored rosectreh institutes, as standing at the cornors of a tetrahedron. In the United States, industry uses the four sources equally and thore is free movomont of peoplo and idous between them - to which is ascribed the fact that industry in the United States has a growth-rate twico that in Britain. He went on to describe the growth of sponsored research institutes, particularly those of Arthur 1. Little, first in the Unitod States and later in Europe. Fnumorating the reasons for the rapid growth of sponsored research institutes, Dr. Woodward cited their independence; the fact that they are professional business orgenizations without other ties such as teaching; and thoir versatility, speed of action and flexibility through a multi-diseiplinary staff (which includes managoment skills). The sponsored research institute obviates the need for a firm to augment its own research facilitios to deal with special problems. They have close tios with acadomic ostablishments and use acadomic consultants regularly. While working for a firm they mako a point of trying to become a temporary but integral part of the management.

Prof. W. E. J. Farvis (Department of Electrical Engineering, University of Edinburgh), while speaking of the relationships between industry and university engineering departments, complained about the difficulty of dociding on suitable student curricula in viow of the changing face of the engineering industry. Ho supported the concept of colleges of advanced technology and the Diploma in Technology, and deplored tho presont desire, partly based on snobbery, for such colleges to become universities. Prof. Farvis wished to see at better liaison and understanding botween industry and academies. Thus, industry could help engineering departments and themselves by promoting research projects and roleasing staff to holp teach design. Next year, in the Departmont of Electrical Engineering at Edinburgh, design experiments will be included in the curriculum to holp the student to feel that he is part of industry as woll as of a university. Prof. Farvis would like suggestions from firms as to small problems, possibly of dubious solutions. Little would be lost financially if thero woro no satisfactory outcomo, but meanwhile students were being trained while worrying at a practical problem in close contact with industry.

W. S. Robertison (chiof oxecutive, Scottish Council for Devolopment and Industry) spoko fluently about the pest, present and future industrial situations in Scotland. Industrial devclopment in Scolland first 'sheared off' from the rest of the world during 1880 -90 although the effects wero scarcely noticeable until tho 1920 's. Until 25 years ago, industry in Scotland suffered from two weaknesses: (1) there was no production of enginocring components in quantity; (2) there was little applied. research. Scotland had only a weak technological push, there were many gaps in the industrial scene, and few opportunitios for graduates. Since 1925 much progresss has been made in getting quantity production and fairly good progress in applied resenrch. Mr. Robertson said that distribution as well as number should be considered with regard to graduates. Ho defined:

$$
\begin{aligned}
\text { Expansive force }= & \text { No. of scientists and ongineors } \\
& \text { multiplied by communications }
\end{aligned}
$$

The pattern of industry is closely associated with the distribution of Government, dofence spending. 'Thus, in south-east Fingland there are many Government research laboratorios; onco these had been establishod, industry rose up to feed them. Tho benefits from tho National Engineering Laboratory, founded in 1947 at East Kilbrido, havo begun to maturo and Mr. Robertson prodieted that this arew of Scotland will become one of the best engineering contres in Europes. Such experience suggests the need for similar Govoriment spending to stimulate industry in other parts of Scotland and tho United Kingdom. For a thriving research community, communications, both physical and intollectual, are vital, and he instanced the growth of the electronics industry in the area around Edinburgh, well served by air and rail, which is expanding at a higher rato than anywhere else in Britain. 'The air service north of the industrial belt, however, is poor, and no direct communication oxists between Scotland and the European Continont.

Sir Hurry Melville (chairman, Science Research Council), speaking on "Collaboration between Industry and Government in Fostering Seientific Research", began by asking for better communications and exchango of personnel botween centres of learning, industry and Government laboratories. The Science Research Council, inaugurated in April 1965 following tho replacement of the Department of Scientific and Industrial Research, has promoted, or will promote, research studentships, fellowships and industrial fellowships at academic institutions, and make grants towards research work undertaken in a resoarch association, sponsored resoarch instituto or industrial laboratory, provided the work is of outstanding public and seientific interest and the recipient of the grant uniquely qualified to undertake it.

The Scionco Research Council is paying about $f 4$ million a year in grants to universities for expensive equipment. Usually the Council stipulates that the equipment bo shared with othor departments and available to outside users. An outstanding example is the Scottish Universities Reactor, which cost $£ 500,000$. However, some oquipment, such as particle accelorators, costing up to $£ 10$ million, is of little direct use to industry.

In tho United States the same proportion of the national income is spent on research as in Britain but the total is ten times as great. Henco, while in the United States some of the national incomo can reasonably be spent on pure research from which no pructical results are expected, Britain should not, he belicvos, do so as a rulc. The Scienco Research Council, however, does mako exceptions, one of which is support for a very expensive spaco science programme.

During discussions several deprecated the 'gap' botwoen the industrial and academic spheres. It was generally agreed to be mutually advantageous for institutions of higher learning to undertake problems suggosted and partly supported by industry and Government departments; however, Prof. Farvis quoted Sir Edward Appleton's remark that research, oven if apparently trivial, sorvos to train the student into thinking in an original manner-which is what is required of the graduate in industry. There is need to attract creative minds into industry. The need for personal communication was emphasized: research workers should go out to nonscientists to persuade them of the desirability and application of particular research ideds.

We look forward to trarklation of the sentiments of the symposium into action.

A. C. Low

A. J. Rostron 